\title{
Palgrave Macmillan/Journal of International Business Studies Decade Award 2003: Foreword from the Editor-in-Chief
}

\section{AY Lewin \\ Editor-In-Chief}

Journal of International Business Studies (2003) 34, 493-494. doi: I0.1057/palgrave. jibs. 8400057
It is a special honor for me to announce that the recipients of the 2003 Palgrave Macmillan/Journal of International Business Studies Decade Award are Professors Bruce Kogut and Udo Zander for their paper, Knowledge of the Firm and the Evolutionary Theory of the MultiNational Corporation, and to present each one of them with a $\$ 1,000$ Award. They also received a leather-bound memorial volume honoring celebrating their recognition.

The Palgrave Macmillan/JIBS Decade Award represents a significant moment in time for the AIB community and the Journal of International Business Studies. It involves an act of self-reflection: an opportunity to assess international business scholarship and its influence beyond the boundaries of the community of international business scholars. I believe that from the inception of the JIBS Decade Award in 1997, an implicit goal was to recognize the influence of international business scholarship on the social science disciplines that anchor international business research. This, of course, requires that some time must elapse before the significance and influence of papers published in JIBS can be determined.

In continuing this tradition, the new Editorial team of JIBS wanted to greatly elevate the significance and visibility of this Award within the Academy of International Business, and to select the Palgrave Macmillan/JIBS Decade Award paper on the basis of influence measures in both international business and disciplinarybased journals.

In order to feature the Palgrave Macmillan/JIBS Decade Award within the AIB, the program chairman for the 2003 Annual Meeting and the AIB Executive Board approved a proposal to announce the Award at a newly designated JIBS Plenary Session on July 6, 2003. This session also featured a report by the Editor to the AIB membership.

The highlight of the event was the presentation of the Award followed by two commentary presentations from Professors Alaine Verbeke and Stephen Tallman, discussing the significance of the 2003 Palgrave Macmillan/JIBS Decade Award paper from two perspectives. A retrospective essay given by Professor Zander followed the commentaries. Both the commentaries and the essay are published in this issue of the Journal of International Business Studies. 
Finally, the JIBS Plenary Session was followed by the first JIBS-Palgrave reception honoring the 2003 Palgrave Macmillan/JIBS Decade Award recipients and offering individuals an opportunity to personally congratulate them.

I wish to express my thanks and sincere appreciation to the AIB Executive Board for their support, to Udo Zander the 2003 AIB program chair, for re- arranging the Annual Meeting program to include the JIBS Plenary Session, to Palgrave Macmillan Publishing for its financial and logistic support and to the 2003 Palgrave Macmillan/JIBS Decade Award Selection Committee: Professors Harry Barkema, Eleanor Westney, Don Lessard and Alan Rugman, as Chairman. 